DOI: $10.31866 / 2616-7654.5 .2020 .205731$

\section{СТРУКТУРА УКРАЇНСЬКОÏ БІБЛІОТЕЧНОÏ АСОЦАЦІї ЯК ОРГАНІЗАЦІЙНА ПРОЕКЦІЯ ПРІОРИТЕТНИХ НАПРЯМІВ ÏÏ ФУНКЦІОНУВАННЯ}

Альона Мотько,

аспірант кафедри інформаційних технологій Київського національного університету культури і мистецтв

(Київ, Україна)

e-mail: alyona94@meta.ua

ORCID: https://orcid.org/0000-0002-5513-882X

Стаття присвячена розгляду діяльності Української бібліотечної асоціації на основі діалектичного підходу та філософських категорій форми і змісту, аналіз яких дає змогу дослідити особливості представництва, управління, пріоритети і розвиток діяльності Української бібліотечної асоціації крізь призму її структури. Для досягнення поставленої мети під час дослідження було використано діалектичний метод, застосування якого обумовило розгляд трансформації структури Української бібліотечної асоціації з позицій iï розвитку; соціальнокомунікаційний, системний, відповідно до якого Українська бібліотечна асоціація розглядалась як відкрита система, що динамічно розвивається і адаптується до нових реалій; структурно-функціональний, у рамках якого було визначено відповідність напрямів функціонування організації її структурним компонентам, аналізу документів, моделювання, описовий. Обгрунтовано структуру Української бібліотечної асоціації як організаційну модель іï пріоритетних напрямів функціонування та управління діяльністю асоціації з реалізації цих напрямів. Виявлено, що структурно-функціональну специфіку Української бібліотечної асоціації визначають провідні фахівці в галузі книгознавства та бібліотекознавства, які є експертами різних сфер бібліотечної діяльності та суттєво впливають на вирішення актуальних питань бібліотечної справи, сприяючи розвитку окремих напрямів розвитку асоціації в рамках роботи відповідних секцій. З’ясовано, що створені секції відображають, з одного боку, проблемно-тематичну спрямованість роботи асоціації, з іншого - увагу до функціонування бібліотек певних типів і видів. Акцентовано, що одним із пріоритетних напрямів діяльності асоціації сьогодні є забезпечення наступності, що організаційно відображено у створенні молодіжної секції. Обгрунтовано, що механізми формування структурних компонентів організаційної системи, відкритість і прозорість діяльності асоціації обумовлює гнучкість її організаційної моделі, що є запорукою адаптивності діяльності Української бібліотечної асоціації до реалій сьогодення.

Ключові слова: бібліотечна справа, Українська бібліотечна асоціація, УБА, асоціації, структура УБА, секції, робочі групи. 
Український журнал з бібліотекознавства та інформаційних наук. Випуск 5 (2020) Ukrainian Journal on Library and Information Science. Issue 5 (2020)

\section{ВСТУП.}

В умовах сьогодення бібліотеки є базовим елементом культурної, наукової, освітньої та інформаційної інфраструктури суспільства. Становлення і підтримка життєдіяльності конкурентоспроможної нації напряму пов’язані зі станом розвитку і ефективністю бібліотечно-інформаційної діяльності.

Важливу роль у розвитку бібліотечної справи в Україні відіграє професійна громадська організація ВГО «Українська бібліотечна асоціація» (далі - УБА), яка $€$ потужною професійною платформою, що здійснює суттєвий вплив на розвиток бібліотечної професії та управління галуззю, сприяє модернізації бібліотечної справи. УБА $є$ тим компонентом громадянського суспільства, який посилює персональну мотивацію до активної дії і впроваджує демократичні практики у професійне бібліотечне середовище. В останнє десятиліття УБА активізувала свою діяльність не лише в напрямі підтримки бібліотечної справи, але й у формуванні суспільної думки стосовно актуальних питань державного і суспільного розвитку - підвищення рівня правової культури, реформи децентралізації, медичної реформи тощо.

\section{ТЕОРЕТИЧНЕ ПІДГРУНТЯ.}

На сьогодні грунтовного наукового осмислення досвіду функціонування УБА, організаційних засад іï діяльності щодо розвитку бібліотечної справи в Україні поки що не відбулося, комплексні наукові праці дисертаційного рівня, присвячені УБА, в бібліотекознавстві відсутні.

Як засвідчив аналіз захищених дисертацій за фаховим спрямуванням, Українська бібліотечна асоціація не була предметом спеціальної наукової уваги. Лише частково її діяльність на етапі становлення була висвітлена В. Пашковою в контексті розгляду еволюції національних бібліотечних асоціацій (1876-2009 рр.) (Пашкова, 2010а). Зокрема, дослідницею було розглянуто виникнення, становлення та напрями діяльності національних бібліотечних асоціацій, серед яких і Української бібліотечної асоціації, як демократичного інституту розвитку професії та управління галуззю.

Вивчення фахової наукової літератури дало змогу з'ясувати, що різні аспекти діяльності УБА згадуються лише в окремих публікаціях вітчизняних науковців, серед яких В. Бабич (Бабич \& Сошинська, 1995), Т. Добко та В. Загуменна (Добко, 2003; Добко \& Загуменна, 1996; Загуменна, 1997), Л. Ковальчук (2010), А. Лисицький (2010), В. Пашкова (2005; 2007; 2010), Я. Сошинська (2012), І. Шевченко (2012) та ін.

Так, бібліотечній адвокації в контексті діяльності УБА присвячено праці Л. Ковальчук (2010), В. Загуменної (2009; 2010; 2013; 2019; 2020), А. Лисицького (2010), В. Пашкової (2007) та ін.

Питання міжнародного співробітництва УБА розкриваються в публікаціях О. Лапської (2017), В. Пашкової (2007; 2010), І. Шевченко (2012) та ін.

Водночас до останнього часу наукове висвітлення діяльності УБА відбувалось епізодично, без застосування широкого спектра теоретико-методологічного інструментарію.

Мета статті. Метою публікації є розгляд діяльності УБА на основі діалектичного підходу та філософських категорій форми і змісту, аналіз яких дасть змогу 
Бібліотечна практика: інформаційні і соціокультурні аспекти Library practice: informational and socio-cultural aspects

дослідити особливості представництва, управління, пріоритети і розвиток діяльності УБА крізь призму її структури. Ідеться про обгрунтування структури УБА як організаційної моделі пріоритетних напрямів функціонування асоціації та управління її діяльністю з реалізації цих напрямів.

\section{МЕТОДИ ТА МАТЕРІАЛИ ДОСЛІДЖЕННЯ.}

Для досягнення поставленої мети під час дослідження було використано діалектичний метод, застосування якого обумовило розгляд трансформації структури Української бібліотечної асоціації з позицій розвитку як самої асоціації, так і її діяльності, соціальнокомунікаційний, системний, відповідно до якого Українська бібліотечна асоціація розглядалась як відкрита система, що динамічно розвивається і адаптується до нових реалій, структурно-функціональний, у рамках якого було визначено відповідність напрямів функціонування організації її структурним компонентам, аналізу документів, моделювання, описовий. Джерельну основу дослідження склали фахові наукові публікації, присвячені різним аспектам діяльності УБА, опубліковані документи асоціації (Українська бібліотечна асоціація, 1996; 1998; 2010), матеріали офіційного сайту УБА.

\section{ВИКЛАД ОСНОВНОГО МАТЕРІАЛУ.}

Як відомо, форма будь-чого перебуває в діалектичному взаємозв’язку зі змістом і значною мірою обумовлюється ним. При цьому зміст визначається як сукупність елементів і процесів, що утворюють даний предмет чи явище. Натомість формою є спосіб існування, внутрішня організація та зовнішнє вираження цього предмета або явища. Зміст і форма не можуть існувати ізольовано одне від одного. Елементи і процеси, що становлять те чи інше явище, стають його змістом, лише набравши певної форми. Своєю чергою, форма завжди має відповідати певному змісту. Безформного змісту не існує в природі так само, як і беззмістовної форми ("Зміст і форма", 2020). Як зазначають О. Решетов і З. Стежко (2013), «під змістом розуміють єдність усіх взаємодіючих елементів даної матеріальної системи. Форма - це принцип організації, впорядкованості того чи іншого змісту. Визначальною стороною змісту є його змінність, а форми - постійність, тому форма $€$ більш консервативною; вона на початковому етапі розвитку об'єкта відповідає змісту, а потім сповільнює його розвиток» (с.159). Набуття певним об'єктом форми засвідчує його змістовну наповненість, наявність певного функціонального навантаження, спроможність до самостійного функціонування і взаємодії 3 навколишнім світом. Під впливом такої взаємодії з часом змістовне наповнення і функціональне призначення об’єкта можуть змінюватися, що позначатиметься у відповідних змінах форми. При цьому здатність до структурних трансформацій визначає адаптивність об'єкта до змінних реалій. 3 іншого боку, консервативність форми може гальмувати розвиток і ставати на заваді реалізації визначених функцій повною мірою.

У процесі дослідження було виявлено, що структурно-функціональну специфіку Української бібліотечної асоціації визначають провідні фахівці в галузі книгознавства та бібліотекознавства, які є провідними вченими, авторитетними фахівцями різних сфер бібліотечної діяльності та здійснюють суттєвий вплив на 
вирішення актуальних питань бібліотечної справи, розробляючи окремі напрями розвитку УБА в рамках роботи відповідних секцій.

Саме за ініціативи активної групи бібліотечних фахівців під час установчої конференції УБА 30 січня - 1 лютого 1995 р. в Києві у приміщенні Будинку вчителя було створено УБА (Бабич \& Сошинська, 1995, с. 16). У витоків організації стояли декан факультету бібліотечно-інформаційних систем Київського державного інституту культури (нині - Київський національний університет культури і мистецтв) В. Бабич, генеральний директор Національної парламентської бібліотеки України (нині - Національна бібліотека України імені Ярослава Мудрого) А. Корнієнко, начальник відділу бібліотек Міністерства культури і мистецтв України В. Навроцька, доцент Київського державного інституту культури В. Пашкова, директор Центральної освітянської бібліотеки П. Рогова, старший викладач Київського державного інституту культури Я. Сошинська та ін. 1 серпня 1995 р. Українська бібліотечна асоціація була зареєстрована в Міністерстві юстиції України (свідоцтво № 675) ("Хроніка подій", 1995). Згідно з даними Реєстру громадських об’єднань, її засновниками стали В. Бабич, А. Корнієнко, В. Пашкова ("Реєстр громадських об'єднань", б. р.).

Станом на березень 2020 р. організаційними елементами структури УБАє: президент УБА, президія, ревізійна комісія, експертна рада, виконавчий офіс, регіональні відділення, вісім секцій та чотири робочі групи з різних напрямів, а саме: секції університетських бібліотек, працівників шкільних бібліотек, працівників публічних бібліотек, працівників медичних бібліотек, з адвокації, «Бібліотека - на допомогу особам з інвалідністю та людям похилого віку», з бібліотечно-інформаційної освіти, молодіжна секція УБА та робочі групи з етики, з електронних книг, «швидкого реагування» на загострення кризи управління галуззю та робоча група УБА з RDA ("Секції, робочі групи", б. р.) (див. рис. 1).

Якщо президент УБА, президія, ревізійна комісія, експертна рада, виконавчий офіс є елементами структури асоціації, спрямованими на виконання управлінської та контролюючої функцій, а регіональні відділення відображають масштаб охоплення УБА, то секції і робочі групи є організаційною проекцією пріоритетних напрямів діяльності і актуальних завдань асоціації.

«Положення про секцію Української бібліотечної асоціації» визначає секцію як структурний підрозділ, що забезпечує професійні аспекти діяльності Української бібліотечної асоціації, завданнями якого є сприяння професіоналізації бібліотечно-інформаційних працівників, удосконаленню організації науково-дослідної роботи, визначення перспективної тематики досліджень і розробок, зміцнення зв'язків бібліотек із науковими установами і учбовими закладами, широке впровадження у практику отриманих наукових результатів (Українська бібліотечна асоціація, 1998, с. 33).

На початку діяльності УБА, станом на 1996 р., у їі складі були сформовані і функціонували такі секції:

- секція «Комплектування і зберігання бібліотечних фондів» (К. Селіверстова, канд. пед. наук, доцент Київського державного інституту культури);

- секція сучасних інформаційно-бібліотечних технологій (керівник Н. Шаронова, д-р техн. наук, професор Харківського державного інституту культури (нині - Харківська державна академія культури)); 


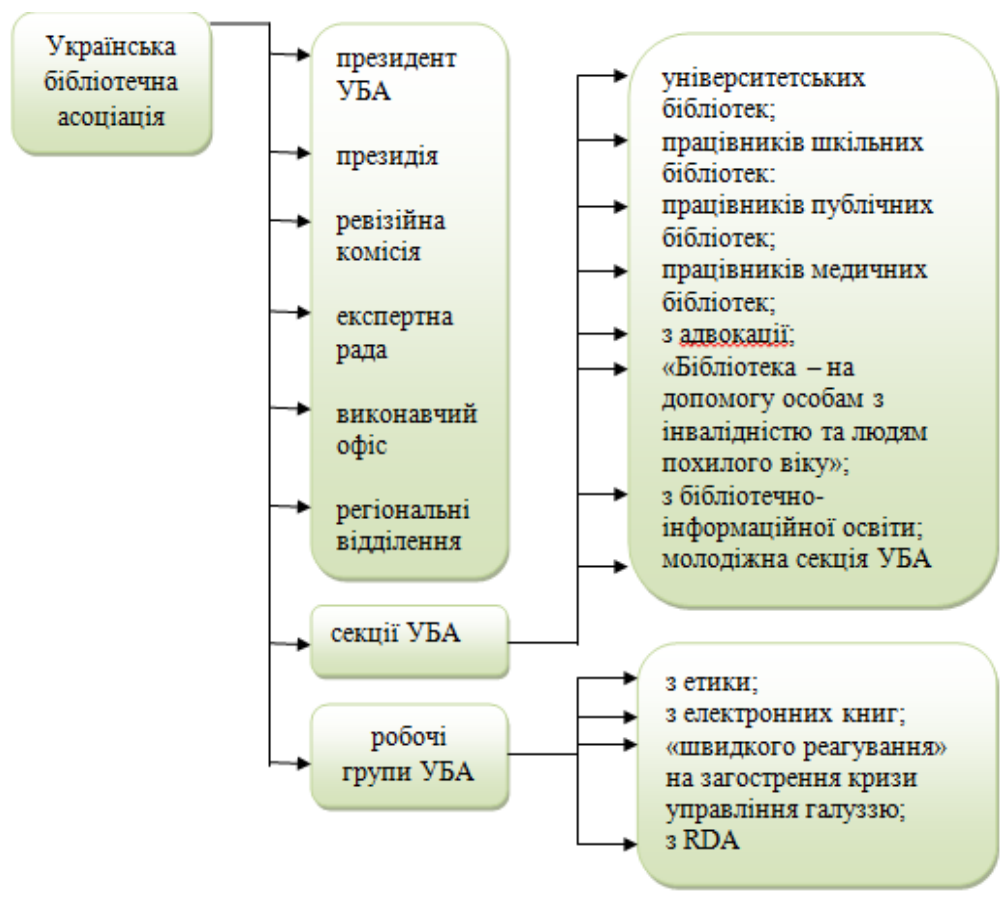

Рuc. 1. Організаційна структура Української бібліотечної асоціації.

- бібліографічна секція (керівники В. Загуменна, канд. пед. наук, професор, зав. кафедрою факультету бібліотечно-інформаційних систем Київського державного інституту культури, та Т. Добко, канд. іст. наук, завідувач відділу довідково-бібліографічним відділом Центральної наукової бібліотеки ім. В. I. Вернадського Національної академії наук України (нині - Національна бібліотека України імені В. І. Вернадського));

- секція безперервної бібліотечно-інформаційної освіти (керівники професор В. Бабич, декан факультету бібліотечно-інформаційних систем, завідувач кафедри Київського державного інституту культури, заслужений працівник культури України, та професор В. Скнар, зав. кафедрою бібліотечної справи Інституту підвищення кваліфікації працівників культури);

- секція соціології та психології бібліотечної справи (керівник А. Чачко, д-р пед. наук, академік Міжнародної академії інформатизації при ООН, зав. кафедрою бібліотекознавства факультету бібліотечно-інформаційних систем Київського державного інституту культури);

- секція працівників публічних бібліотек (керівник Л. Ковальчук, директор Центральної міської бібліотеки ім. Лесі Українки м. Києва, заслужений працівник культури України);

- секція працівників дитячих бібліотек (керівник А. Кобзаренко, директор Державної бібліотеки України для дітей, заслужений працівник культури України). Згодом була створена окрема Асоціація дитячих бібліотек; 
- секція працівників медичних бібліотек (керівник С. Науменко, головний бібліотекар Державної наукової медичної бібліотеки України);

- секція працівників сільськогосподарських бібліотек (керівник Р. Целінський, директор Центральної наукової сільськогосподарської бібліотеки Української академії аграрних наук);

- секція працівників бібліотек вищих учбових закладів (керівник Т. Ярошенко, директор наукової бібліотеки Національного університету «Києво-Могилянська академія»);

- секція працівників освітянських бібліотек (керівник П. Рогова, директор Центральної освітянської бібліотеки) (Українська бібліотечна асоціація, 1996).

Поряд із секціями станом на 1996 р. було сформовано три «круглі столи»:

- «Наукові дослідження в галузі бібліотечно-інформаційної справи» (керівники К. Селіверстова, канд. пед. наук, доцент Київського державного інституту культури, та М. Слободяник, д-р іст. наук, директор Інституту бібліотекознавства Центральної наукової бібліотеки ім. В. І. Вернадського Національної академії наук України);

- «Етика бібліотечного працівника» (керівник Л. Каліберда, канд. іст. наук., професор, зав. кафедрою бібліотекознавства Київського державного інституту культури);

- «Міжнародне бібліотечне співробітництво» (керівник В. Пашкова, канд. пед. наук, доцент факультету бібліотечно-інформаційних систем Київського державного інституту культури) (Українська бібліотечна асоціація, 1996).

Як дав змогу виявити аналіз документів і матеріалів УБА, секції, які створювались в асоціації під час її функціонування, відображали, з одного боку, проблемно-тематичну спрямованість роботи асоціації (як-от секції комплектування і збереження бібліотечних фондів, законодавства у сфері бібліотечної справи та інформатизації,бібліографічна секція, секції історії книжкової і бібліотечної справи, безперервної бібліотечно-інформаційної освіти, краєзнавчої роботи бібліотек, соціології та психології бібліотечної справи), з іншого - увагу до функціонування бібліотек певних типів і видів (секції освітянських бібліотек, публічних бібліотек, дитячих бібліотек, бібліотек вищих учбових закладів тощо). Така структуризація обумовлена не лише важливістю окреслених напрямів діяльності, а й наявністю експертного потенціалу саме в цих сферах. Тобто фахова спроможність і експертний рівень тих, хто закладав підвалини для роботи асоціації, визначили її початкові обриси.

Так, наприклад, достатньо промовистим є приклад Т. Ярошенко, очільниці на початку роботи асоціації секції працівників бібліотек вищих учбових закладів. До 1995 р. - часу створення УБА - Т. Ярошенко працювала старшим бібліотекарем, завідувачем відділу і заступником директора Державної бібліотеки України для юнацтва (1986 - 1994 рр.), згодом старшим викладачем Київського державного інституту культури (1994 - 1995 рр.), а 1995 р. була призначена директором наукової бібліотеки Національного університету «Києво-Могилянська академія».

Так само відомими фахівцями в галузі бібліографії є В. Загуменна і Т. Добко, тож логічно, що під їхнім керівництвом напрям бібліографії оформився в окрему секцію УБА. 
Бібліотечна практика: інформаційні і соціокультурні аспекти Library practice: informational and socio-cultural aspects

Інший приклад - створення секції книжкової і бібліотечної справи, на чолі якої стала відомий книгознавець Т. Ківшар, яка 1996 р. захистила докторську дисертацію «Український книжковий рух: книговидання та книгопоширення (19171923 рр.)».

При цьому діяльність асоціації розбудовувалася не лише за науковими напрямами (секції, «круглі столи»), а і за територіальним принципом (створення регіональних відділень та осередків).

Згідно з документами і матеріалами УБА, станом на 1996 р. було створено 16 регіональних відділень асоціації: Кіровоградське обласне відділення УБА, Кримське відділення УБА, Чернівецьке, Дніпропетровське Чернігівське, Рівненське, Вінницьке, Житомирське, Херсонське, Луганське, Одеське, Волинське, Закарпатське, Донецьке, Тернопільське, Сумське регіональні відділення УБА (Українська бібліотечна асоціація, 1996, с. 14-16).

Потужними осередками УБА стали відділення УБА при Київському державному інституті культури, при Національній парламентській бібліотеці України, при Центральній науковій сільськогосподарській бібліотеці, при Центральній міській бібліотеці ім. Лесі Українки, при Державній історичній бібліотеці України, при Державній бібліотеці України для юнацтва, при Державній бібліотеці України для дітей, а також Освітянський осередок УБА, Первинне відділення Української бібліотечної асоціації при Харківській державній науковій бібліотеці ім. В. Г. Короленка та Харківське галузеве відділення (АСІБТ) УБА (Українська бібліотечна асоціація, 1996, с. 14-16).

Згодом у структурі асоціації відповідно до її розвитку, зміни умов, потреб і пріоритетів відбувалась реорганізація - з'являлись нові органи, формувались одні і зникали інші секції, круглі столи та відділення.

Так, набуття діяльністю УБА комплексного, багатовимірного і системного характеру обумовило створення 2010 р. виконавчого офісу УБА в складі виконавчого директора (Я. Сошинська), PR-менеджера (О. Бояринова), адміністративного координатора Виконавчого офісу (з 2011 р.) (В. Польова), ІТ-спеціаліста (Р. Лойко), а 2018 р. - ухвалення положення про експертну раду УБА як постійно діючий консультативно-дорадчий орган асоціації для обговорення, оцінки та підготовки висновків або рекомендацій щодо діяльності організації.

Посилення адвокаційного напряму діяльності УБА, намагання консолідувати бібліотечну спільноту з метою захисту і представлення інтересів бібліотек та їх користувачів перед органами державної влади та місцевого самоврядування обумовило створення 2008 р. секції Української бібліотечної асоціації з адвокації.

Залучення до діяльності УБА молоді позначилось у формуванні в складі асоціації 2012 р. молодіжної секції Української бібліотечної асоціації.

3 іншого боку, припинилась діяльність бібліографічної секції та секції історії книжкової і бібліотечної справи, комплектування і збереження бібліотечних фондів та законодавства у сфері бібліотечної справи та інформатизації, соціології та психології бібліотечної справи, секції працівників дитячих бібліотек та краєзнавчої роботи бібліотек, а 2019 р. було ухвалено рішення про реорганізацію одразу двох секцій - студентської секції УБА (яка об’єдналась із молодіжною секцією) та секції директорів ОУНБ (яку було об’єднано із секцією працівників публічних бібліотек). 
Багато в чому така ситуація обумовлюється не стільки вирішенням усіх нагальних проблем, якими опікувалися названі секції, скільки браком відповідного кадрового ресурсу, адже низка фахівців, які стояли біля витоків організації, через різні обставини припинили активну діяльність в асоціації або трансформували їі напрям (як-от, наприклад, В. Загуменна, яка від початку очолювала бібліографічну секцію, згодом доклала зусиль до створення секції з адвокації, а нині є керівником секції з бібліотечно-інформаційної освіти).

Водночас, незважаючи на скорочення кількості секцій, як і на початку створення УБА, кожна 3 них опікується специфічним напрямом та проводить свою діяльність відповідно до встановленої місії, завдань та цілей. Так само, як і на початку діяльності УБА, склад секцій відображає як типо-видові особливості бібліотек, працівники яких беруть участь у діяльності УБА, так і проблемно-тематичні аспекти діяльності асоціації. Зокрема, на сьогодні, поряд із секціями працівників публічних бібліотек, університетських бібліотек та освітянських бібліотек, в УБА створена і функціонує секція працівників медичних бібліотек. За проблемно-тематичними напрямами сформовано секцію «Бібліотека - на допомогу особам з інвалідністю та людям похилого віку» і секцію з бібліотечно-інформаційної освіти.

Секція університетських бібліотек УБА об’єднує працівників бібліотек вищих навчальних закладів України, даючи широкі можливості у обміні досвідом та ідеями. Свої зусилля секція спрямовує на «сприяння інформаційному забезпеченню університетської науки та підвищенню якості освіти в країні, впровадженню кращих стандартів бібліотечно-інформаційного обслуговування університетських громад країни та зростанню ролі та місця університетської бібліотеки в структурі кожного університету» ("Секція університетських бібліотек УБА", б. р.).

Секція працівників шкільних бібліотек об'єднує працівників шкільних бібліотек, зусилля яких спрямовані на «створення нової сучасної моделі шкільної бібліотеки, спроможної на якісно новому рівні забезпечувати інформаційні потреби тих, хто вчить, та тих, хто навчається» ("Секція працівників шкільних бібліотек", б. р.). Серед пріоритетів секції - зміцнення інформаційної бази системи національної освіти та розвитку інформаційно-освітнього середовища навчальних закладів, а також посилення ролі шкільних бібліотек як освітніх та культурних центрів.

У секції працівників публічних бібліотек беруть участь директори та спеціалісти публічних бібліотек, які об’єднують свої зусилля стосовно координації роботи публічних бібліотек із розвитку бібліотечної справи ("Секція працівників публічних бібліотек", б. р.). У 2019 р. до секції була приєднана створена у 2010 р. секція директорів ОУНБ (реорганізована), яка опікувалась діяльністю обласних універсальних наукових бібліотек.

Пріоритетом діяльності секції працівників медичних бібліотек визначено сприяння розвитку та удосконаленню функціонування медичних бібліотек України, а також їх інтеграції у міжнародний інформаційний простір ("Секція працівників медичних бібліотек", б. р.).

Сфера діяльності проблемно-тематичної секції з адвокації полягає в представленні, просуванні і захисті інтересів вітчизняних бібліотек та їх користувачів, їх лобіюванні перед органами державної влади та місцевого самоврядування, різни- 
Бібліотечна практика: інформаційні і соціокультурні аспекти Library practice: informational and socio-cultural aspects

ми громадськими структурами. Секція прагне привернути увагу суспільства і влади до бібліотек для зміни іміджу книгозбірень в Україні ("Секція з адвокації", б. р.).

Обміном професійною інформацією з питань обслуговування людей з інвалідністю та людей похилого віку, надання їм послуг з використанням новітніх технологій через проведення конференцій, форумів, семінарів, тренінгів, зокрема 3 використанням технології інтернету, опікується секція «Бібліотека - на допомогу особам з інвалідністю та людям похилого віку» ("Секція «Бібліотека - на допомогу особам...»", б. р.).

Секція з бібліотечно-інформаційної освіти «спрямовує свої зусилля на розвиток бібліотечно-інформаційної освіти в Україні, підвищення якості освіти, впровадження кращих світових стандартів у підготовку висококваліфікованих бібліотечно-інформаційних фахівців, які стануть конкурентоспроможними на міжнародному ринку праці» ("Секція з бібліотечно-інформаційної освіти", б. р.).

Крім цього, особливістю сучасного етапу розвитку УБА, порівняно з початковим, стало виокремлення структурного компоненту не лише за проблемно-тематичною або типо-видовою ознакою, а і за віковою - ним стала молодіжна секція УБА, яка має на меті розвиток та удосконалення бібліотечної справи в Україні ("Молодіжна секція УБА", б. р.). Функціонування у складі організації молодіжної секції УБА засвідчує увагу асоціації до забезпечення наступності вироблених у процесі її діяльності успішних громадських практик та методичних підходів, спрямоване на збереження її спроможності і життєвого потенціалу формування умов для збереження лідерського потенціалу організації - підготовки молодого покоління бібліотечних лідерів.

Крім секцій, Українська бібліотечна асоціація для виконання поставлених перед нею питань формує спеціальні робочі групи, які мають спеціально створені команди для виконання поставлених перед ними завдань, а саме: робоча група з етики, робоча група з електронних книг, робоча група УБА «швидкого реагування» на загострення кризи управління галуззю та робоча група УБА з RDA (правила каталогізації).

Віртуальною проекцією організаційної структури УБА є створений 1 березня 1998 р. офіційний сайт Української бібліотечної асоціації (підготували: керівник секції сучасних інформаційних технологій О. Архипська, президент В. Пашкова, керівник секції працівників університетських бібліотек Т. Ярошенко) ("Хроніка подій", 1998).

\section{ВИСНОВКИ.}

Отже, структура Української бібліотечної асоціації відображає комплексний характер її діяльності як потужної організації, яка здійснює істотний вплив на розвиток бібліотечної справи України та формування сучасних українських книгозбірень. Організаційна структура УБА формується з урахуванням актуальних проблем бібліотечної галузі та покликана сприяти ефективності їх вирішення. Аналіз структурних компонентів організаційної моделі УБА на основі діалектичного підходу та філософських категорій форми і змісту дає змогу простежити еволюцію діяльності асоціації в умовах поширення новітніх електронних технологій та реформування бібліотечної галузі. Структура УБА, яка відповідає філософській категорії форми, змінюється в залежності від пріоритетних напрямів діяльності 
та завдань асоціації, які є змістовною складовою її функціонування і обумовлюються актуальними потребами і наявним кадровим потенціалом. Водночас, незмінність таких структурних компонентів організації, як президент, президія, ревізійна комісія, експертна рада та виконавчий офіс, додає функціонуванню асоціації необхідної стабільності і керованості в умовах невизначеності, якими характеризується сучасний етап становлення інформаційного суспільства.

\section{СПИСОК ПОСИЛАНЬ}

Бабич В. С., Сошинська Я. Є. Установча конференція Української бібліотечної асоціації. Бібліотечний вісник. 1995. № 3. С. 16-18.

Добко Т. Бібліотечні асоціації. Енциклопедія Сучасної України. Київ, 2003. Т. 2. С. 734-735.

Добко Т. В., Загуменна В. В. Засідання бібліографічної секції Української бібліотечної асоціації. Бібліотечний вісник. 1996. № 5. С. 31-32.

Загуменна В. В. «Адвокасі» без перешкод: про актуальну проблему сьогодення: потребу вільного та відкритого доступу до інформації. День. 2010. 12 серп. С. 7. URL: https:// cutt.ly/btI13WD (дата звернення: 15.02.2020).

Загуменна В. В. Адвокасі бібліотек: мета, завдання, перспективи розвитку. Документознавство. Бібліотекознавство. Інформаційна діяльність: проблеми науки, освіти, практики : зб. матеріалів VI Міжнар. наук.-практ. конф., 21-23 трав. 2009 р., Київ. Київ, 2009. C. $112-114$.

Загуменна В. В. Адвокація в бібліотечній сфері. Українська бібліотечна енциклопедія. 14.01.2020. URL: http://ube.nlu.org.ua/article/Адвокація (дата звернення: 15.02.2020).

Загуменна В. В. Адвокація: представлення інтересів бібліотек : посіб. для бібліотекарів за прогр. підвищення кваліфікації / Укр. бібл. асоц., Нац. акад. керів. кадрів культури і мистецтв, Центр безперерв. інформ.-бібл. освіти, Голов. тренінг. центр для бібліотекарів. Київ : Самміт-Книга, 2013. 80 с.

Загуменна В. В. Адвокація як важливий напрям діяльності сучасної бібліотеки. Вісник Книжкової палати. 2019. № 4. С. 25-28.

Загуменна В. Участь публічних бібліотек у роботі бібліографічної секції Української бібліотечної асоціації. Публічні бібліотеки: сучасність і майбутнє : зб. ст. до Міжнар. наук.-практ. конф. / УБА та ін. Київ. 1997. С. 75-79.

Зміст і форма. Leksika.com.ua. URL: https://cutt.ly/DtI0eqL (дата звернення: 15.02.2020).

Ковальчук Л. І. Українська бібліотечна асоціація на захисті інтересів бібліотек. БібліоТек@. 2010. № 2. C. 1-2. URL: https://cutt.ly/0tI0oHm (дата звернення: 15.02.2020).

Лапська О. О. Міжнародне співробітництво Української бібліотечної асоціації в контексті міжкультурної комунікації. Бібліотекознавство. Документознавство. Інформологія. 2017. № 1. С. 108-114.

Лисицкий А. В. Из состояния «как сейчас» в состояние «как должно быть» (Библиотечная адвокация). Современная библиотека. 2010. № 3. С. 10-17.

Молодіжна секція УБА. Українська бібліотечна асоціація. URL: https://cutt.ly/ztI0R8M (дата звернення: 15.02.2020).

Пашкова В. С. Внесок національних бібліотечних асоціацій у формування іміджу бібліотеки в суспільстві й підвищення престижу бібліотечної професії. Бібліотечний форум України. 2007. № 1. С. 50-56.

Пашкова В. Дванадцять років програмам бібліотечних обмінів із США. Бібліотечна планеma. 2005. № 1. С. 14-15.

Пашкова В. С. Еволюція національних бібліотечних асоціацій (1876-2009) : автореф. дис.... д-ра іст. наук : 27.00.03. Київ, 2010. 40 с. 
Пашкова В. Українська бібліотечна асоціація: аналіз реалізації стратегічних напрямів розвитку в 2006-2009 роках. Вісник Книжкової палати. 2010. № 2. С. 19-25.

Реєстр громадських об’єднань. Міністерство юстиції України. URL: https://cutt.ly/ktSqoiq (дата звернення: 15.02.2020).

Решетов О.О.,Стежко 3.В.Класичнатеорія розвитку.Діалектика.Науковізаписки. Кіровоград, 2013. Вип.13. С. 156-159. URL: http://dspace.kntu.kr.ua/jspui/handle/123456789/4613 (дата звернення: 15.02.2020).

Секція «Бібліотека - на допомогу особам з інвалідністю та людям похилого віку». Українська бібліотечна асоціація. URL: https://cutt.ly/btI2wA2 (дата звернення: 15.02.2020).

Секція з адвокації. Українська бібліотечна асоціація. URL: https://cutt.ly/DtI2kiu (дата звернення: 15.02.2020).

Секція з бібліотечно-інформаційної освіти. Українська бібліотечна асоціація. URL: https:// cutt.ly/mtI2TjW (дата звернення: 15.02.2020).

Секція працівників медичних бібліотек. Українська бібліотечна асоціація. URL: https://cutt. ly/ttI2NIA (дата звернення: 15.02.2020).

Секція працівників публічних бібліотек. Українська бібліотечна асоціація. URL: https://cutt. ly/etI2hJ0 (дата звернення: 15.02.2020).

Секція працівників шкільних бібліотек. Українська бібліотечна асоціація. URL: https://cutt. ly/utI25yj (дата звернення: 15.02.2020).

Секція університетських бібліотек УБА. Українська бібліотечна асоціація. URL: https://cutt. ly/2tI9wBw (дата звернення: 15.02.2020).

Сошинська Я. Є., Сошинська В. Є., Бояринова О. Є. Середовище професійного спілкування: теорія і практика. Наукові праці Державної науково-педагогічної бібліотеки України імені В. О. Сухомлинського. Київ, 2012. Вип. 3. С. 245-255.

Українська бібліотечна асоціація : документи і матеріали / уклад.: Бабич В. С., В. С. Пашкова. Київ, 1996. 30 с.

Українська бібліотечна асоціація : документи і матеріали / уклад.: Пашкова В. С., Бабич В. С. Київ, 1998.80 с.

Українська бібліотечна асоціація : документи і матеріали, 2001-2009 рр. / уклад.: Пашкова В. С., Добко Т. В., Дригайло В. Г. 5-те вид., допов. і перероб. Київ : Самміт-Книга, 2010. 144 с.

Секції, робочі групи. Українська бібліотечна асоціація. URL: https://ula.org.ua/sekciyi-kruglistoli (дата звернення: 15.02.2020).

Хроніка подій - 1995. Українська бібліотечна асоціація. URL: https://cutt.ly/ZtI9jwI (дата звернення: 15.02.2020).

Хроніка подій - 1998. Українська бібліотечна асоціація. URL: https://cutt.ly/8tI91Kt (дата звернення: 15.02.2020).

Шевченко I. Міжнародна співпраця - важливий напрям роботи Української бібліотечної асоціації (нотатки з Форуму бібліотекарів у Астані). Бібліотечна планета. 2012. № 4. C. $6-8$.

\section{REFERENCES}

Babych, V. S., \& Soshynska, Ya. Ye. (1995). Ustanovcha konferentsiia Ukrainskoi bibliotechnoi asotsiatsii [Constituent Conference of the Ukrainian Library Association]. Bibliotechnyi visnyk, 3, 16-18 [in Ukrainian].

Dobko, T.(2003). Bibliotechni asotsiatsii [LibraryAssosiations]. InEntsyklopediia Cuchasnoi Ukrainy [Entsyklopedia of Modern Ukraine] (Vol. 2, pp. 734-735). Instytut entsyklopedychnykh doslidzhen NAN Ukrainy [in Ukrainian]. 
Dobko, T. V., \& Zahumenna, V. V. (1996). Zasidannia bibliohrafichnoi sektsii Ukrainskoi bibliotechnoi asotsiatsii [Meeting of the bibliographic section of the Ukrainian Library Association]. Bibliotechnyi visnyk, 5, 31-32 [in Ukrainian].

Zahumenna, V. V. (2010, August, 12). "Advokasi" bez pereshkod: pro aktualnu problemu sohodennia: potrebu vilnoho ta vidkrytoho dostupu do informatsii ["Advocacy" without interruption: on the current problem of the present: the need for free and open access to information]. Den, 7. https://day.kyiv.ua/uk/article/kultura/advokasi-bez-pereshkod [in Ukrainian].

Zahumenna, V. V. (2009). Advokasi bibliotek: meta, zavdannia, perspektyvy rozvytku [Advocacy of libraries: purpose, objectives, prospects]. In Dokumentoznavstvo. Bibliotekoznavstvo. Informatsiina diialnist: problemy nauky, osvity, praktyky [Documentary science. Library Science. Information activities: problems of science, education, practice], Proceedings of the 6th Internetional Scientific and Practical Conference (pp. 112-114). National Academy of Culture and Arts Management [in Ukrainian].

Zahumenna, V. V. (2020). Advokatsiia v bibliotechnii sferi [Advocacy in the library field]. In Ukrainska bibliotechna entsyklopediia. http://ube.nlu.org.ua/article/Адвокація [in Ukrainian].

Zahumenna, V. V. (2013). Advokatsiia: predstavlennia interesiv bibliotek [Advocacy: Representing Libraries]. Sammit-Knyha [in Ukrainian].

Zahumenna, V. V. (2019). Advokatsiia yak vazhlyvyi napriam diialnosti suchasnoi biblioteky [Advocacy as an important direction of the activity of modern library]. Bulletin of the Book Chamber, 4, 25-28 [in Ukrainian].

Zahumenna, V. (1997). Uchast publichnykh bibliotek u roboti bibliohrafichnoi sektsii Ukrainskoi bibliotechnoi asotsiatsii [Participation of public libraries in the work of the bibliographic section of the Ukrainian Library Association]. In Publichni biblioteky: suchasnist i maibutnie [Public libraries: present and future], Proceedings Internetional Scientific and Practical Conference (pp. 75-79). Ukrainian Library Association [in Ukrainian].

Ukrainska Radianska Entsyklopediia. (n.d.). Zmist i forma [Content and form].Retrieved Februar 15, 2020, from https://leksika.com.ua/16410921/ure/zmist_i_forma [in Ukrainian].

Kovalchuk, L. I. (2010). Ukrainska bibliotechna asotsiatsiia na zakhysti interesiv bibliotek [Ukrainian library association on behalf of the interests of libraries].BiblioTek@, 2, 1-2. https://cutt.ly/LtSqKlj [in Ukrainian].

Lapska, O. O. (2017). Mizhnarodne spivrobitnytstvo ukrainskoi bibliotechnoi asotsiatsii v konteksti mizhkulturnoi komunikatsii [International cooperation of the Ukrainian library association in the context of intercultural communication]. Bibliotekoznavstvo. Dokumentoznavstvo. Informolohiia, 1, 108-114 [in Ukrainian].

Lisitskii, A. V. (2010). Iz sostoianiia "kak seichas" v sostoianie "kak dolzhno byt" (Bibliotechnaia advokatsiia) [From the state "as it is now" to state "as it should be" (Library Advocacy)]. The modern Library magazin, 3, 10-17 [in Russian].

Ukrainian Library Association. (n.d.). Molodizhna sektsiia UBA [Youth section of ULA]. Retrieved February 15, 2020, from https://cutt.ly/ztIOR8M [in Ukrainian].

Pashkova, V. S. (2007). Vnesok natsionalnykh bibliotechnykh asotsiatsii u formuvannia imidzhu biblioteky v suspilstvi i pidvyshchennia prestyzhu bibliotechnoi profesii [The contribution of national library associations to the image of the library in society in raising the prestige of the library profession]. Bibliotechnyi forum Ukrainy, 1, 50-56 [in Ukrainian].

Pashkova, V. S. (2005). Dvanadtsiat rokiv prohramam bibliotechnykh obminiv iz SShA [Twelve years of library exchange programs from the United States]. Bibliotechna planeta, 1, 14-15 [in Ukrainian].

Pashkova, V. S. (2010a). Evoliutsiia natsionalnykh bibliotechnykh asotsiatsii (1876-2009) [Evolution of national library associations (1876-2009)] (Extended abstract of Doctor's thesis). Natsionalna biblioteka Ukrainy im. V.I.Vernadskoho NAN Ukrainy, Kyiv [in Ukrainian]. 
Pashkova, V. (2010b). Ukrainska bibliotechna asotsiatsiia: analiz realizatsii stratehichnykh napriamiv rozvytku v 2006-2009 rokakh [Ukrainian Library Association: Analysis of Implementation of Strategic Directions for Development in 2006-2009]. Bulletin of the Book Chamber, 2, 19-25.

Ministerstvo yustytsii Ukrainy.(n.d.). Reiestr hromadskykh obiednan [Register of public associations]. Retrieved February 15, 2020, from https://cutt.ly/ktSqoiq [in Ukrainian].

Reshetov, O. O., \& Stezhko Z. V. (2013). Klasychna teoriia rozvytku. Dialektyka [Classic theory of development. Dialectics]. Naukovi zapysky, 13, 156-159. https://cutt.ly/YtI00Gj [in Ukrainian].

Ukrainska bibliotechna asotsiatsiia.(n.d.). Sektsiia "Biblioteka - na dopomohu osobam z invalidnistiu ta liudiam pokhyloho viku" [The Section "Library - to help people with disabilities and the elderly"]. Retrieved February 15, 2020, from https://cutt.ly/btI2wA2 [in Ukrainian].

Ukrainian Library Association. (n.d.). Sektsiia z advokatsii [Advocacy Section]. Retrieved February 15, 2020, from https://cutt.ly/DtI2kiu [in Ukrainian].

Ukrainian Library Association (n.d.). Sektsiia z bibliotechno-informatsiinoi osvity [Library and Information Education]. Retrieved February 15, 2020, from https://cutt.ly/mtI2TjW [in Ukrainian].

Ukrainian Library Association. (n.d.). Sektsiia pratsivnykiv medychnykh bibliotek [Medical Library Workers Section]. Retrieved February 15, 2020, from https://cutt.ly/ttI2NIA [in Ukrainian].

Ukrainian Library Association. (n.d.). Sektsiia pratsivnykiv publichnykh bibliotek [Public Library Workers Section]. Retrieved February 15, 2020, from https://cutt.ly/etI2hJ0 [in Ukrainian].

Ukrainian Library Association. (n.d.). Sektsiia pratsivnykiv shkilnykh bibliotek [School libraries staff section]. Retrieved February 15, 2020, from https://cutt.ly/utI25yj [in Ukrainian].

Ukrainian Library Association. (n.d.). Sektsiia universytetskykh bibliotek UBA [UBA University Libraries Section]. Retrieved February 15, 2020, from https://cutt.ly/2tI9wBw [in Ukrainian].

Soshynska, Ya. Ye., Soshynska, V. Ye., \& Boyarynova, O. Ye. (2012). Seredovyshche profesiinoho spilkuvannia: teoriia i praktyka [The Professional Communication Environment: Theory and Practice]. Naukovi pratsi Derzhavnoi naukovo-pedahohichnoi biblioteky Ukrainy imeni V. O. Sukhomlynskoho, 3, 245-255 [in Ukrainian].

Babych, V. S., \& Pashkova, V. S. (Comps.). (1996). Ukrainska bibliotechna asotsiatsiia: dokumenty i materialy [Ukrainian Library Association: Documents and Materials]. Ukrainian Library Association [in Ukrainian].

Babych, V. S., \& Pashkova, V. S. (Comps.). (1998). Ukrainska bibliotechna asotsiatsiia: dokumenty i materialy [Ukrainian Library Association: Documents and Materials]. Ukrainian Library Association [in Ukrainian].

Pashkova, V.S., Dobko, T. V., \& Dryhailo. V.H.(Comps.). (2010). Ukrainska bibliotechna asotsiatsiia: dokumenty i materialy, 2001-2009 rr. [Ukrainian Library Association: Documents and Materials, 2001-2009] (5th ed.). Sammit-Knyha [in Ukrainian].

Ukrainian Library Association. (n.d.). Sektsii, robochi hrupy [Sections, working groups]. Retrieved February 15, 2020, from https://ula.org.ua/sekciyi-krugli-stoli [in Ukrainian].

Ukrainian Library Association. (1995). Khronika podii - 1995 [Chronicle of Events - 1995]. https:// cutt.ly/ZtI9jwI [in Ukrainian].

Ukrainian Library Association. (1998). Khronika podii -1998 [Chronicle of Events -1998]. https:// cutt.ly/8tI9lKt [in Ukrainian].

Shevchenko, I. (2012). Mizhnarodna spivpratsia - vazhlyvyi napriam roboty Ukrainskoi bibliotechnoi asotsiatsii (notatky z Forumu bibliotekariv u Astani) [International cooperation is an important direction of the work of the Ukrainian Library Association (notes from the Forum of Librarians in Astana)]. Bibliotechna planeta, 4, 6-8 [in Ukrainian]. 
UDC 061.2:021.6(477)

\author{
Alyona Motko, \\ Postgraduate Student of the Information \\ Technologies Department at Kyiv National University \\ of Culture and Arts (Kyiv, Ukraine) \\ e-mail:alyona94@meta.ua \\ ORCID: https://orcid.org/0000-0002-5513-882X
}

\title{
STRUCTURE OF THE UKRAINIAN LIBRARY ASSOCIATION AS AN ORGANIZATIONAL PROJECTION OF PRIORITY DIRECTIONS OF ITS FUNCTIONING
}

The article deals with the activity of the Ukrainian Library Association on the basis of the dialectical approach and philosophical categories of form and content, the analysis of which allows to explore the features of representation, management, priorities and development of the activities of the Ukrainian Library Association through the prism of its structure. During the research in order to achieve this goal, a dialectical method was used, the application of which led to a consideration of the transformation of the Ukrainian Library Association structure from the standpoint of the development of both the association and its activity, social-communicative and systemic methods, according to which the Ukrainian Library Association was considered as an open system, which develops dynamically and adapts to new realities, structural and functional method, within which the conformity of the directions of the functioning of the organization with its structural components was determined, methods of document analysis, modelling and descriptive. The structure of the Ukrainian Library Association is substantiated as an organizational model of priority directions of its functioning and management of the association's activities in realization of these directions. It is revealed that the structural and functional specifics of the Ukrainian Library Association are determined by leading experts in the field of book and librarianship, who are experts in different spheres of library activity and have a significant influence on solving topical issues of library affairs, developing separate directions of the association's development within the work of relevant sections. It has been found that the sections created reflect, on the one hand, the thematic orientation of the association, and on the other, attention to the functioning of libraries of certain types and types. It is emphasized that one of the priority directions of the Association's activity nowadays is ensuring continuity, which is organizationally reflected in the creation of the Youth Section. It is substantiated that the mechanisms of formation of structural components of the organizational system, openness and transparency of the activity of the association determines the flexibility of its organizational model, which is a guarantee of the adaptability of the activities of the Ukrainian Library Association to the realities of today.

Keywords: library business, Ukrainian Library Association, ULA, associations, structure ULA, sections, working groups. 